\title{
Development of a Chatbot Program for Follow-Up Management of Workers' General Health Examinations in Korea: A Pilot Study
}

\author{
Byeong Jin Ye ${ }^{1}$, Ju Young Kim ${ }^{2}$, Chunhui Suh ${ }^{1}$, Seong Pil Choi ${ }^{1}$, Maro Choi ${ }^{1}$, Dong Hyun Kim ${ }^{1}$ \\ and Byung Chul Son ${ }^{1, *}$
}

Citation: Ye, B.J.; Kim, J.Y.; Suh, C.; Choi, S.P.; Choi, M.; Kim, D.H.; Son, B.C. Development of a Chatbot Program for Follow-Up Management of Workers' General Health

Examinations in Korea: A Pilot Study Int. J. Environ. Res. Public Health 2021, 18, 2170. https://doi.org/10.3390/ ijerph18042170

Academic Editors: Holly Blake,

Natalia Stanulewicz, Maria Armaou, Jukka Takala and Paul B. Tchounwou

Received: 5 December 2020

Accepted: 19 February 2021

Published: 23 February 2021

Publisher's Note: MDPI stays neutral with regard to jurisdictional claims in published maps and institutional affiliations.

Copyright: (c) 2021 by the authors. Licensee MDPI, Basel, Switzerland. This article is an open access article distributed under the terms and conditions of the Creative Commons Attribution (CC BY) license (https:/ / creativecommons.org/licenses/by/ $4.0 /)$.
1 Department of Occupational and Environmental Medicine \& Institute of Environmental and Occupational Medicine, Busan Paik Hospital, Inje University, Busan 47392, Korea; yebj_oem@paik.ac.kr (B.J.Y.); chsuh@paik.ac.kr (C.S.); oemos83@gmail.com (S.P.C.); akfh1325@gmail.com (M.C.); oemkdh@gmail.com (D.H.K.)

2 Colorbot Inc., Busan 49324, Korea; jooykim@pusan.ac.kr

* Correspondence: sonbc007@hanmail.net; Tel.: +82-51-890-6142; Fax: +82-51-893-3523

\begin{abstract}
Background: Follow-up management of workers' general health examination (WGHE) is important, but it is not currently well done. Chatbot, a type of digital healthcare tool, is used in various medical fields but has never been developed for follow-up management of WGHE in Korea. (2) Methods: The database containing results and explanations related to WGHE was constructed. Then, the channel, which connects users with the database was created. A user survey regarding effectiveness was administered to 23 healthcare providers. Additionally, interviews on applicability for occupational health services were conducted with six nurses in the agency of occupational health management. (3) Results: Chatbot was implemented on a small scale on the Amazon cloud service (AWS) EC2 using KaKaoTalk and Web Chat as user channels. Regarding the effectiveness, 21 (91.30\%) rated the need for chatbots as very high; however, $11(47.83 \%)$ rated the usability as not high. Of the 23 participants, 14 (60.87\%) expressed overall satisfaction. Nurses appreciated the chatbot program as a method for resolving accessibility and as an aid for explaining examination results and follow-up management. (4) Conclusions: The effectiveness of WGHE and the applicability in the occupational health service of the chatbot program for follow-up management can be confirmed.
\end{abstract}

Keywords: chatbot; follow-up management; occupational health service; workers' general health examination

\section{Introduction}

A health examination provides an effective screening and medical evaluation strategy that has been scientifically shown to facilitate early detection and treatment, even among asymptomatic patients, thereby preventing disease and promoting personal health [1]. In Korea, business owners are obligated by the Industrial Safety and Health Act to participate in the workers' general health examination (WGHE) program as one element of efforts to protect workers' health. The general health examination covered by the National Health Insurance Service can be substituted for the WGHE [2]. Since 2009, the general health examination in Korea has identified cardiocerebrovascular disease as the main target disease, and the program has focused on improving lifestyles and strengthening follow-up management through a health risk assessment [3].

Follow-up management for the general health examination entails additional interventions, such as diagnosis confirmation, education, and counselling, regarding results of the examination for those who need further action after the screening [4]. The importance and effectiveness of follow-up management are well known from previous studies. In many studies, the risk factors for cardiocerebrovascular diseases, such as smoking, drinking, exercise, eating habits, blood pressure, and blood sugar, were improved in the group with 
specific follow-up management, compared to the group without it [5-7]. However, in the past studies in Korea, only $35.5 \%$ of people who needed a follow-up confirmation examination after the initial examination followed through with the confirmation examination [8]. Also, only $2.21 \%$ and $1.18 \%$, respectively, of patients who needed hypertension and diabetes treatment based on the general health examination were treated within 90 days [2]. These results indicate that even if a medical issue is identified during the general health examination, proper follow-up is often neglected.

Chatbot, a type of digital healthcare tool, is a rule-based or artificial intelligence-based communication software that uses a mobile device to provide answers and relevant information in response to questions posed through text or voice conversations [9]. This technology is increasingly used for applications in credit scoring [10] and marketing strategies [11] due to the universalization of smart devices and mobile (online) communication and the expanding influence of messenger apps. Recently, chatbots have been increasingly used as a tool for digital healthcare. For example, the chatbot program "Kohby" at Kangbuk Samsung Hospital provides information on health check-ups and administrative services such as appointments or payments [12]. In addition, the chatbot also provides appropriate answers to questions about symptoms and diseases, and connects the patient with an appropriate doctor through "HealthTap" [13] and "Babylon Healthcare" [14]. The chatbot additionally provides information regarding treatment and management for cancer patients [15,16] or interventions for stress [17] or mental health problems [18]. Furthermore, chatbot also plays a role in motivating and sustaining lifestyle changes, for example, quitting smoking $[19,20]$.

Because chatbots are optimised for mobile devices and can therefore obtain the necessary information without the need to install a separate app, the number of users and the service area are becoming increasing significantly. However, no chatbot program has yet been developed that explains the results of the general health examination explicitly and provides methods for follow-up management, that are easily understood by the general public.

This pilot study is the first step in a plan to develop a chatbot program for follow-up management of the WGHE. The study develops an early version of a chatbot program that generates health status information and health management methods based on individual results from the WGHE. Furthermore, this study investigates the effectiveness of the chatbot program to healthcare providers who have undergone WGHE program in 2018 and the applicability of the chatbot program to nurses in the special agency of occupational health management in charge follow-up management of WGHE.

\section{Materials and Methods}

\subsection{Setting and Participants}

Research participants were recruited from October to November 2019. The research director visited three hospitals and explained the purpose of the study, the contents of the study, and the method of participation for those who received the WGHE in 2018. In addition, consent was obtained from those who agreed to participate in the study. Subsequently, chatbot authentication and personal data were collected after using the chatbot program for a week, a survey was conducted online. Research participants submit their own phone number, and the researcher sends a channel subscription message to the participant's phone number. It is authenticated through the consent of the channel subscription, and data is generated based on the inputted health examination results and information appropriate to one's health status is sent to the individual. Also, the chatbot program was explained to nurses working at the agency of occupational health management. They checked the entire contents of the chatbot program for a week and then participated in the interview. The study was approved by the Institutional Review Board of Busan Paik Hospital, Inje University (No. 19-0189). 


\subsection{Chatbot Program Development}

The chatbot program was developed based on the rule-based or scenario method that is most often used to describe professional content. The development process is as follows.

1. Requirements analysis: Define business requirements for program development.

2. Scenario flow definition: Define the flow of core tasks to which the program is applied and the flow design for providing examination results.

3. Database construction: Design and build the schema for the examination results and additional explanation database. At this time, construct images and videos that will be useful for explaining the examination results.

4. Channel establishment: Set the channel where the user and chatbot will meet.

5. Chatbot program development: Develop a content-provided chatbot program and a chatbot program that extracts and provides necessary answers.

The chatbot program for follow-up management of the WGHE is implemented on a small instance of the Amazon cloud service (AWS) EC2 and web server; the development language node is 7.0, and the database management system is MySQL 5.7. KakaoTalk and Web Chat are used as user channels. After the user performs personal authentication through a smartphone, the program provides follow-up information based on individual results. Using the health examination results, a scenario-based process is used to create a response by linking to or searching the database, web search engine, and YouTube API (Application Programming Interface) for data suitable for the patient's status and examination results (Figure 1).

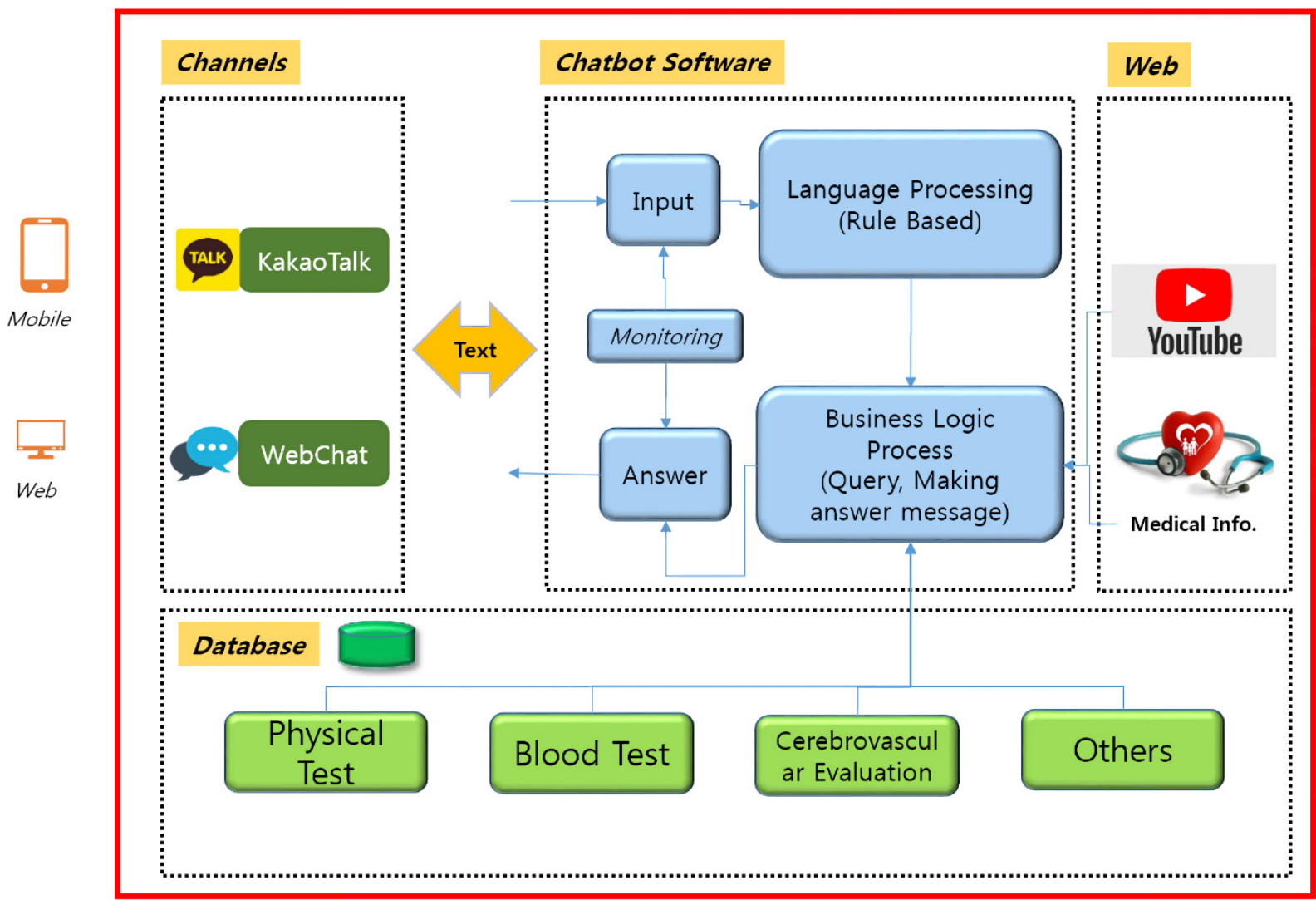

Figure 1. The overall system configuration of the chatbot program.

Personal authentication is required only once, at the first access, and subsequent identification is automatic based on the phone number. After authentication, only the authenticated user's information is displayed on the corresponding smartphone. Smartphone implementation is shown in Figure 2. 


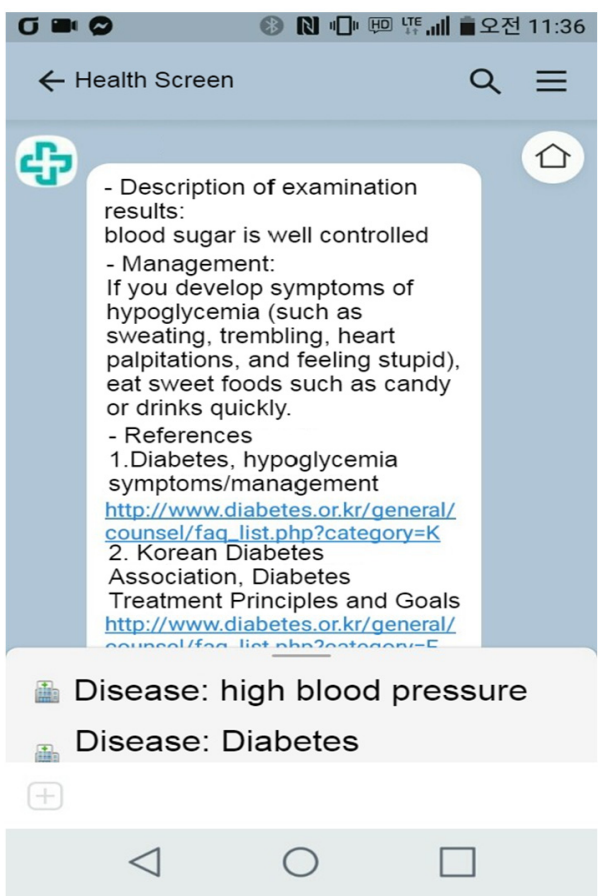

[Result \& basic follow-up: Diabetic pt]

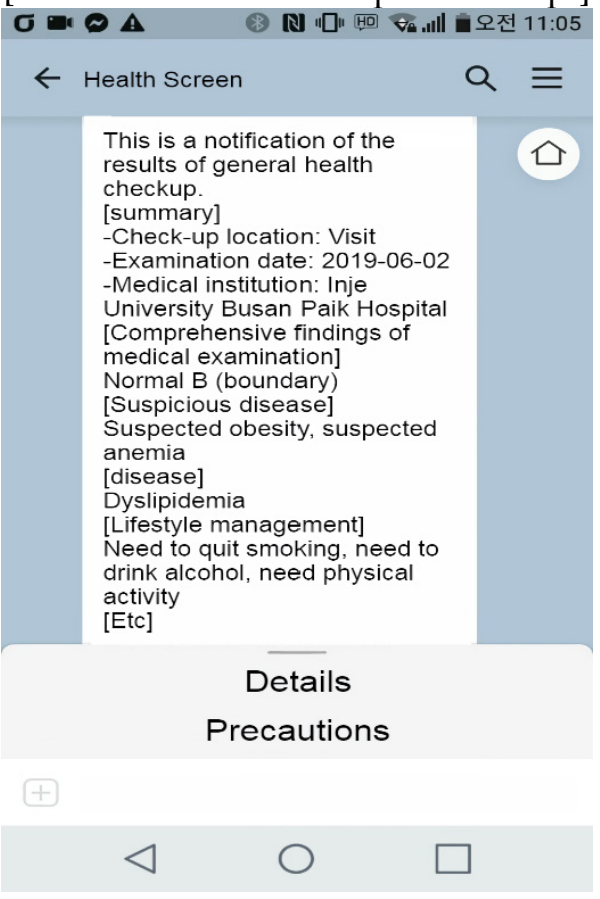

[Comprehensive conclusion]

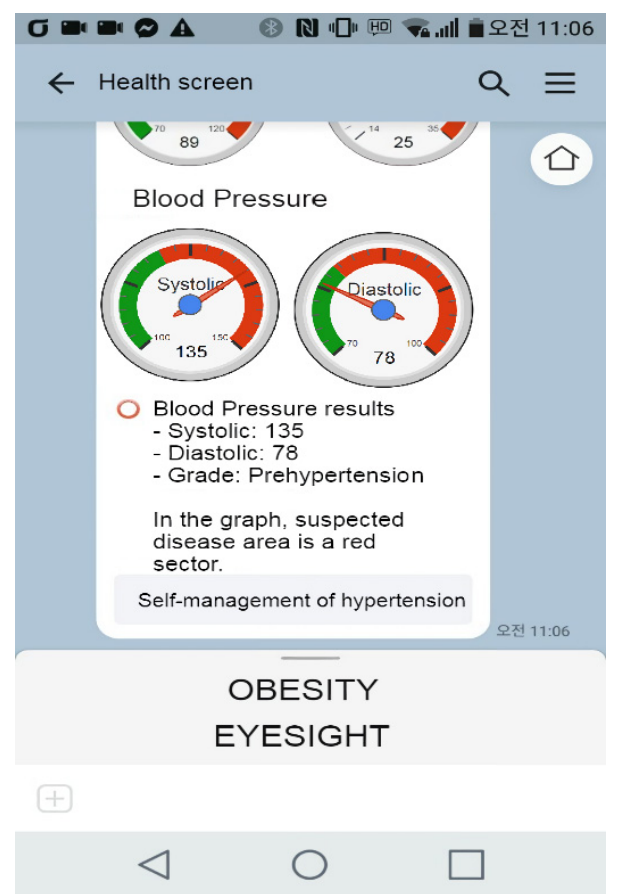

[Blood pressure measurement]

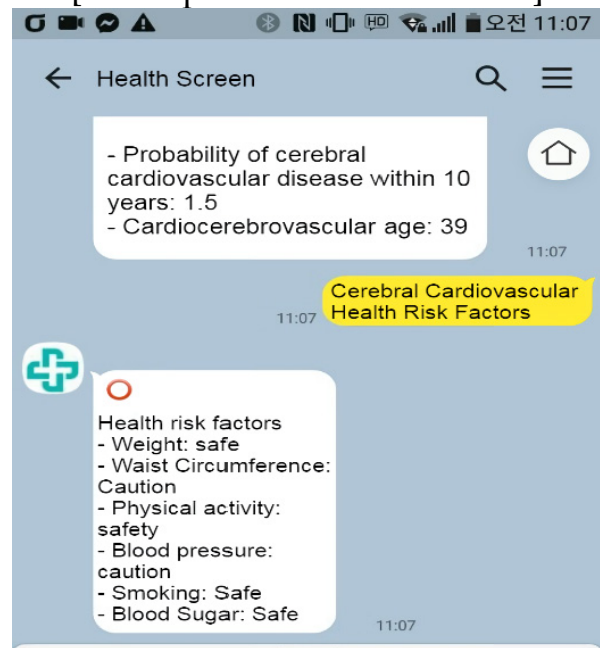

Cardiovascular Risk Status

Cardiovascular Risk Factors

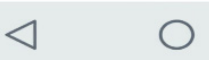

[Risk assessment in CCVD]

Figure 2. Contents of the chatbot program implemented on a smartphone.

Information on study participants' examination results was extracted from the examination results server if that server was accessible. In the case of subjects who have undergone the WGHE program at other hospitals, who would not have access to the examination results server, the examinee printed the examination results and then submitted them. The collected examination results were then stored on a different server. A separate database was built, and after the testing and service period, it was discarded to protect 
personal information. To test the business logic and accuracy of the data display, a separate web program was developed (Figure 3) to enter, add, modify, and delete data.

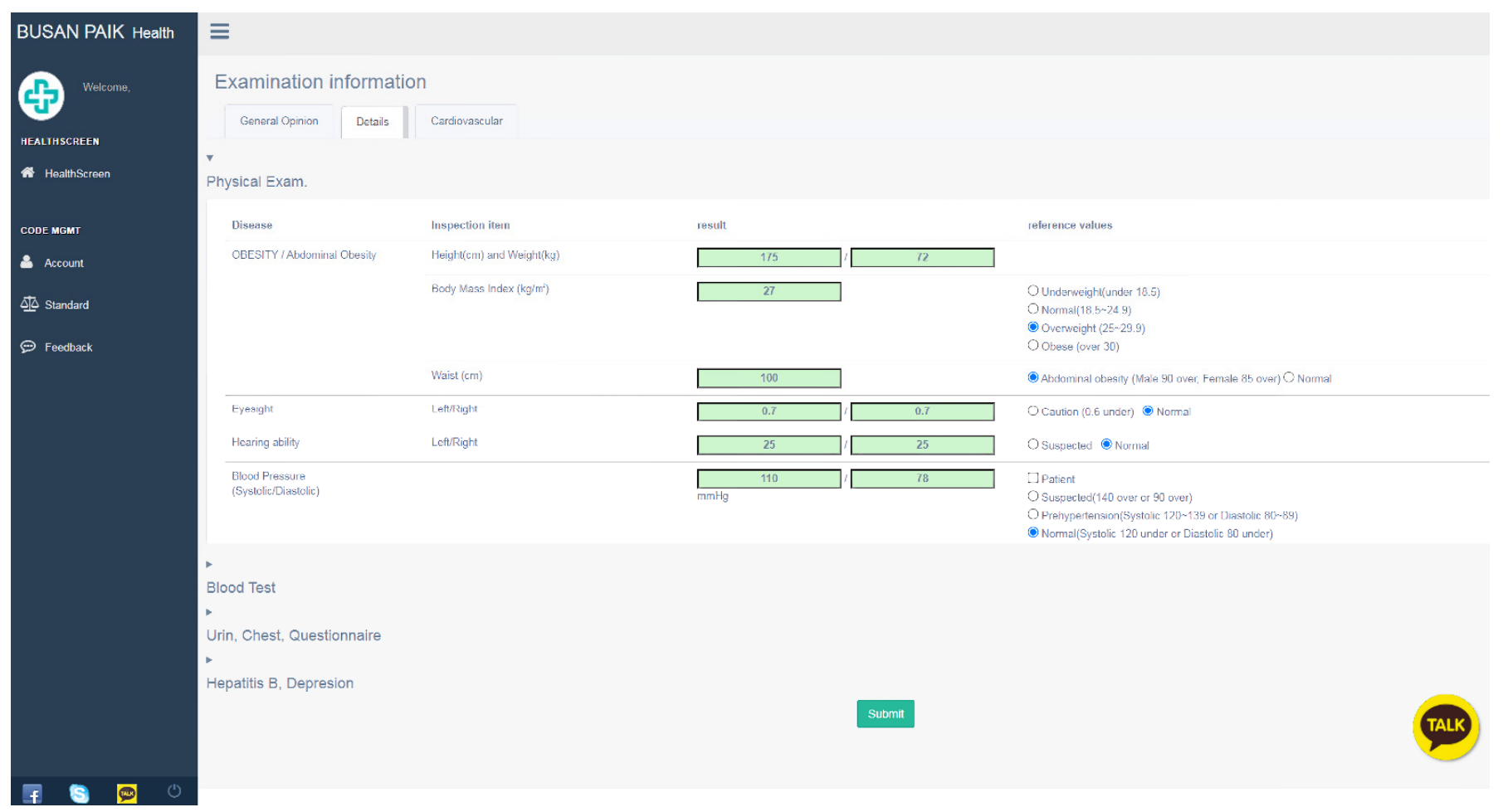

Figure 3. Web program to check the examination data and results in the chatbot program.

\subsection{Program Content Development}

The target diseases of the WGHE in Korea are hypertension, obesity, anaemia, diabetes, dyslipidaemia, liver disease, kidney disease, pulmonary tuberculosis, other chest diseases, and cardiocerebrovascular disease. The history-taking and physical examinations cover past personal and family history and lifestyle factors, body measurements, chest radiography, blood tests, urine tests and risk assessment for cardiocerebrovascular disease.

The content of the program comprises two stages. The first step explains the examination results according to the test items (for example, blood pressure management state: pre-hypertensive stage, which is a blood pressure higher than normal-this is highly likely to develop into hypertension in the future) and basic recommended follow-up management (e.g., "periodic blood pressure measurement is necessary-you should eat a low-salt diet, lose weight through regular exercise, and stop smoking"). The second step requires researching and organising more detailed information than that presented in the basic results (e.g., definition and classification of hypertension) and more detailed follow-up methods than those provided as basic follow-up management (e.g., a method for self-measurement of blood pressure).

This information is provided by government agencies (National Health Insurance Service in Korea, Korea Disease Control and Prevention Agency (KDCA), National Cancer Control Institute in Korea), professional medical associations in Korea (Korean Society for the Study of Obesity, Korean Society of Hypertension, Korean Diabetes Association, The Korean Society of Lipid and Atherosclerosis, Korean Society of Nephrology, Korean Association for the Study of the Liver), and homepages of universities or general hospitals (Samsung Seoul Hospital, Seoul National University Hospital). Five occupational and environmental medicine specialists reviewed the summary of examination results, details of follow-up management, and specific information for each disease. 


\subsection{Effectiveness Survey and Applicability Interview}

An eight-question survey addressing satisfaction with the chatbot was administered, including its necessity and convenience, to 23 medical personnel working at hospitals in Korea (Appendix A). They had data for the 2018 WGHE and agreed to use the chatbot program for follow-up management.

Six nurses were interviewed, in charge of follow-up management of WGHE (Workers' general health examination) regarding the possibility of using the chatbot program for follow-up management at the agency of occupational health management.

They reviewed all the contents of the chatbot program for follow-up management and applied the chatbot program through an app before they took part in the interview. The interview had three aims: (1) the reason why follow-up management was difficult; (2) to evaluate the chatbot program for follow-up management; and (3) to assess the possibility of using the chatbot program in the occupational health service.

\subsection{A Data Analysis}

The questionnaire was constructed using a 5-point Likert scale, but in the results, responses were aggregated into three categories. Very high and slightly high were classified as high, middle as moderate, and slightly low and low as low, and the results in the applicability interview were decided through a meeting of the researchers. Similar opinions were organized into one content and independent opinions were described as they were in the interview.

\section{Results}

\subsection{Chatbot Program Contents}

The program content is divided into two parts. The first includes the examination results, reference value for each test, a basic explanation of the result and actions to be taken. The second part contains detailed information about the examination results (definition and complications of target disease) and recommended managements (exercise, diet). Detailed information and sources are shown in Table 1.

Table 1. Specific information and sources for follow-up management according to target diseases.

\begin{tabular}{|c|c|c|}
\hline Target ds & Specific Information & Source of Information \\
\hline \multirow{3}{*}{ CCVD } & $\begin{array}{l}\text { 1. Definition of cardiocerebrovascular ds and } \\
\text { preventive lifestyle }\end{array}$ & \multirow{3}{*}{$\begin{array}{l}\text { https:// www.youtube.com/watch?v=HcM3pVhDLFY } \\
\text { (accessed on } 3 \text { May 2019) } \\
\text { https://www.youtube.com/watch?v=vttGkiDOQwc } \\
\text { (accessed on } 7 \text { May 2019) } \\
\text { http://www.stroke.or.kr/study/movie.php } \\
\text { (accessed on } 8 \text { May 2019) }\end{array}$} \\
\hline & 2. Prevention of cardiocerebrovascular disease & \\
\hline & $\begin{array}{l}\text { 3. Early symptom of cardiocerebrovascular } \\
\text { disease }\end{array}$ & \\
\hline \multirow{6}{*}{ obesity } & 1. Effects of exercise in obesity & \multirow{6}{*}{ 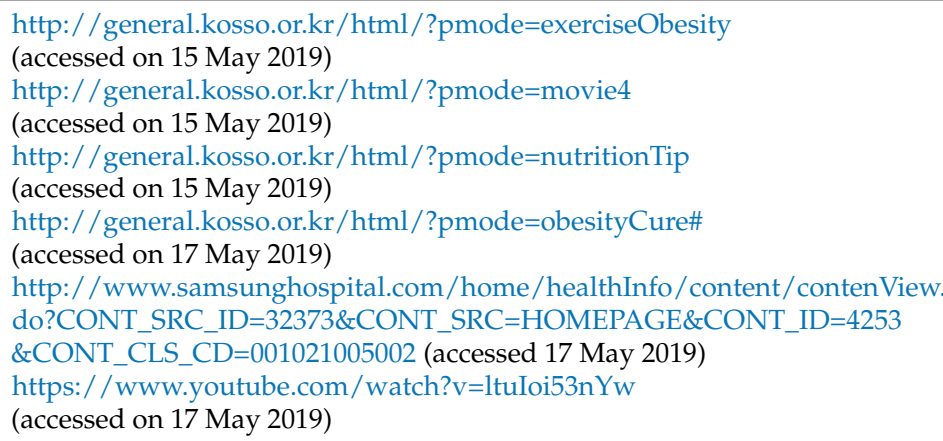 } \\
\hline & 2. Various exercise methods & \\
\hline & 3. Dietary tips for weight control & \\
\hline & $\begin{array}{l}\text { 4. Various managements of obesity (meal, } \\
\text { exercise, treatment) }\end{array}$ & \\
\hline & 5. Eating habits of obesity by meal type & \\
\hline & $\begin{array}{l}\text { 6. Physical activity/nutrition management for } \\
\text { obesity }\end{array}$ & \\
\hline \multirow{2}{*}{ drinking } & $\begin{array}{l}\text { 1. Moderate drinking and proper drinking } \\
\text { method }\end{array}$ & \multirow{2}{*}{$\begin{array}{l}\text { https://www.youtube.com/watch?v=1U58J7Hy8Qg } \\
\text { (accessed on } 18 \text { May 2019) } \\
\text { http:// www.nosmokeguide.go.kr/lay2/program/S1T50C55/nosmoke/ } \\
\text { noSmoke_selftest/noSmoke_selftest1_2q.do } \\
\text { (accessed on } 18 \text { May 2019). }\end{array}$} \\
\hline & 2. Self-diagnosis of alcohol dependence & \\
\hline
\end{tabular}


Table 1. Cont.

\begin{tabular}{|c|c|c|}
\hline Target ds & Specific Information & Source of Information \\
\hline \multirow{6}{*}{ hypertension } & 1. Definition of hypertension & $\begin{array}{l}\text { https://www.youtube.com/watch?v=SL_kKGCyfdo } \\
\text { (accessed on } 2 \text { June 2019) }\end{array}$ \\
\hline & 2. Complications of hypertension & $\begin{array}{l}\text { https: / / www.youtube.com/watch?v=BFEPoWNln- } 8 \\
\text { (accessed on } 2 \text { June 2019) }\end{array}$ \\
\hline & 3. Treatment(drug) of hypertension & $\begin{array}{l}\text { https: / / www.youtube.com/watch?v=Kg_ds77-Y64 } \\
\text { (accessed on 2 June 2019) }\end{array}$ \\
\hline & $\begin{array}{l}\text { 4. Lifestyle management for hypertensive } \\
\text { patients }\end{array}$ & $\begin{array}{l}\text { https: / / www.youtube.com / watch?time_continue }=144 \& v=u \text { PETHTb69E8 } \\
\text { (accessed on } 7 \text { June 2019) }\end{array}$ \\
\hline & 5. Exercise method for blood pressure control & $\begin{array}{l}\text { https:/ / www.youtube.com/watch?v=jwv62FFnBRs } \\
\text { (accessed on } 7 \text { June 2019) }\end{array}$ \\
\hline & 6. Diet to control blood pressure & $\begin{array}{l}\text { https: / / www.youtube.com/watch?v=uvrPNIimWW4 } \\
\text { (accessed on } 7 \text { June 2019) }\end{array}$ \\
\hline \multirow{3}{*}{ smoking } & $\begin{array}{l}\text { 1. Risk of smoking, smoking cessation effect, } \\
\text { drug therapy }\end{array}$ & $\begin{array}{l}\text { https://www.youtube.com/watch?v=8hpAmvjHpuk } \\
\text { (accessed on } 8 \text { June 2019) }\end{array}$ \\
\hline & 2. Self-diagnosis of nicotine addiction & $\begin{array}{l}\text { http:/ / www.nosmokeguide.go.kr/lay2/program/S1T50C9/nosmoke/ } \\
\text { noSmoke_selftest/noSmoke_selftest1_1q.do } \\
\text { (accessed on } 8 \text { June 2019). }\end{array}$ \\
\hline & $\begin{array}{l}\text { 3. Find a smoking cessation clinic(public } \\
\text { health) }\end{array}$ & $\begin{array}{l}\text { http:/ / www.nosmokeguide.go.kr/lay2/program/S1T68C107/nosmoke/ } \\
\text { centermap/bogun_list.do } \\
\text { (accessed on } 8 \text { June 2019). }\end{array}$ \\
\hline \multirow{9}{*}{ Diabetes } & 1. Diabetes definition and classification & $\begin{array}{l}\text { https:/ / www.youtube.com/watch?time_continue=1\&v=PyiZ_nPoFWo } \\
\text { (accessed on } 6 \text { July 2019) }\end{array}$ \\
\hline & 2. Complications of diabetes & \\
\hline & (1) diabetic foot & $\begin{array}{l}\text { https://www.youtube.com/watch?v=Mhxc196ivUc } \\
\text { (accessed on } 6 \text { July 2019) }\end{array}$ \\
\hline & (2) Peripheral neuropathy & $\begin{array}{l}\text { https: / / www.youtube.com/watch?v=Idr-BRKRlH4 } \\
\text { (accessed on } 8 \text { July 2019) }\end{array}$ \\
\hline & (3) Kidney complications & $\begin{array}{l}\text { https: / / www.youtube.com/watch?time_continue }=197 \& v=\text { PN-afvhKEhI } \\
\text { (accessed on } 8 \text { July 2019) }\end{array}$ \\
\hline & 3. Diabetes medication & $\begin{array}{l}\text { https: / / www.youtube.com / watch?v=KGYgHmqBIM0 } \\
\text { (accessed on } 8 \text { July 2019) }\end{array}$ \\
\hline & $\begin{array}{l}\text { 4. Hypoglycemia symptoms and } \\
\text { managements }\end{array}$ & $\begin{array}{l}\text { http://www.diabetes.or.kr/general/counsel/faq_list.php?category=K } \\
\text { (accessed on } 10 \text { July 2019) }\end{array}$ \\
\hline & 5. Exercise in Diabetes & $\begin{array}{l}\text { https:/ / www.youtube.com/watch?time_continue=122\&v=D2A0ZudD6Vo } \\
\text { (accessed on } 10 \text { July 2019) }\end{array}$ \\
\hline & 6. Diabetes Meal & $\begin{array}{l}\text { http:/ / www.diabetes.or.kr/general/food/index.php } \\
\text { (accessed on } 10 \text { July 2019) }\end{array}$ \\
\hline \multirow{6}{*}{ Dyslipidaemia } & 1. Types and meaning of cholesterol & $\begin{array}{l}\text { http: } / / \text { www.lipid.or.kr } / \text { bbs } / \text { index.html? code=animation\&category }=1 \& \\
\text { gubun=\&keyfield=\&key=\&mode=view\&number }=933 \\
\text { (accessed on } 17 \text { July 2019) }\end{array}$ \\
\hline & 2. Complications of dyslipidaemia & $\begin{array}{l}\text { http: / } / \text { www.lipid.or.kr } / \text { bbs } / \text { index.html?code=animation\&category }=1 \& \\
\text { gubun=\&keyfield=\&key=\&mode=view \&number=931 } \\
\text { (accessed on } 17 \text { July 2019) }\end{array}$ \\
\hline & $\begin{array}{l}\text { 3. Risk factors and treatment goals of } \\
\text { dyslipidaemia }\end{array}$ & $\begin{array}{l}\text { http: / } / \text { www.lipid.or.kr } / \text { bbs } / \text { index.html? } \text { code=animation\&category }=1 \& \\
\text { gubun=\&keyfield=\&key=\&mode=view \&number }=929 \\
\text { (accessed on } 19 \text { July 2019) }\end{array}$ \\
\hline & 4. Correcting lifestyle habits of dyslipidaemia & $\begin{array}{l}\text { http: / } / \text { www.lipid.or.kr } / \text { bbs } / \text { index } . \text { html? } \text { code }=\text { animation\&category }=1 \& \\
\text { gubun=\&keyfield=\&key }=\& \text { mode }=\text { view } \& \text { number }=930 \\
\text { (accessed on } 19 \text { July 2019) }\end{array}$ \\
\hline & 5. Exercise of dyslipidaemia & $\begin{array}{l}\text { http: / } / \text { www.lipid.or.kr } / \text { bbs } / \text { index.html? code=animation\&category }=1 \& \\
\text { gubun=\&keyfield=\&key=\&mode }=\text { view \&number }=926 \\
\text { (accessed on } 19 \text { July 2019) }\end{array}$ \\
\hline & 6. Diet for dyslipidaemia & $\begin{array}{l}\text { http: / / www.lipid.or.kr } / \text { bbs } / \text { index.html?code=animation\&category }=1 \& \\
\text { gubun=\&keyfield=\&key=\&mode=view \&number }=924 \\
\text { (accessed on } 20 \text { July 2019) }\end{array}$ \\
\hline \multirow{4}{*}{ Anaemia } & 1. Comment on anaemia test results & $\begin{array}{l}\text { https://youtu.be/aqxwwTln4jc } \\
\text { (accessed on } 23 \text { July 2019) }\end{array}$ \\
\hline & $\begin{array}{l}\text { 2. Causes, symptoms, and complications of } \\
\text { anaemia }\end{array}$ & $\begin{array}{l}\text { https://health.cdc.go.kr/healthinfo/biz/health/gnrlzHealthInfo/ } \\
\text { gnrlzHealthInfo/gnrlzHealthInfoView.do } \\
\text { (accessed on } 23 \text { July 2019) }\end{array}$ \\
\hline & 3. Anaemia and Meal Therapy & $\begin{array}{l}\text { http: / / www.samsunghospital.com/home } / \text { healthInfo / content } / \text { contenView. } \\
\text { do?CONT_SRC_ID=09a4727a80018c1c\&CONT_SRC=CMS\&CONT_ID=2318 } \\
\text { \&CONT_CLS_CD=001020002 } \\
\text { (accessed on } 23 \text { July 2019) }\end{array}$ \\
\hline & 4. Anaemia medication & $\begin{array}{l}\text { https: / / www.youtube.com/watch?v=qvvxdKn4y3U } \\
\text { (accessed on } 23 \text { July 2019) }\end{array}$ \\
\hline
\end{tabular}


Table 1. Cont.

\begin{tabular}{|c|c|c|}
\hline Target ds & Specific Information & Source of Information \\
\hline \multirow{5}{*}{$\begin{array}{l}\text { Kidney } \\
\text { disease }\end{array}$} & 1. The meaning of urine protein test & $\begin{array}{l}\text { https: / / www.youtube.com/watch?v=t5KJk0v9ZZM } \\
\text { (accessed on } 21 \text { August 2019) }\end{array}$ \\
\hline & $\begin{array}{l}\text { 2. Serum creatinine and Implications of the } \\
\text { GFR (Glomerular Filtration Rate) }\end{array}$ & $\begin{array}{l}\text { https: / / www.youtube.com/watch?v=967CeHgF3rc } \\
\text { (accessed on } 21 \text { August 2019) }\end{array}$ \\
\hline & 3. Acute kidney disease & $\begin{array}{l}\text { http:/ / www.ksn.or.kr/sub10/sub01_03.html } \\
\text { (accessed on } 23 \text { August 2019) }\end{array}$ \\
\hline & 4. Chronic kidney disease & $\begin{array}{l}\text { http:/ / www.ksn.or.kr/sub10/sub01_02.html } \\
\text { (accessed on } 23 \text { August 2019) } \\
\text { https: }\end{array}$ \\
\hline & 5. Diet management in kidney disease & $\begin{array}{l}\text { //www.dietitian.or.kr/work/business/kb_c_kidney_glomerulonephritis.do } \\
\text { (accessed on } 23 \text { August 2019) }\end{array}$ \\
\hline \multirow{7}{*}{$\begin{array}{c}\text { Liver } \\
\text { disease }\end{array}$} & 1. Means of liver function test & $\begin{array}{l}\text { https: / / www.youtube.com/watch?v=mmOEl4z-G9I } \\
\text { (accessed on } 27 \text { August 2019) }\end{array}$ \\
\hline & 3. Possible symptoms of liver damage & $\begin{array}{l}\text { https: } / \text { terms.naver.com } / \text { entry.nhn? } \text { docId }=2704268 \& \text { cid }=55588 \& \\
\text { categoryId }=55588 \& \text { expCategoryId }=55588 \\
\text { (accessed on } 27 \text { August 2019) }\end{array}$ \\
\hline & $\begin{array}{l}\text { 4. Definition and management of viral } \\
\text { hepatitis }\end{array}$ & $\begin{array}{l}\text { https: / } / \text { terms.naver.com } / \text { entry.nhn?docId }=2704287 \& \text { cid }=55588 \& \\
\text { categoryId }=55588 \\
\text { (accessed on } 28 \text { August 2019) }\end{array}$ \\
\hline & 5. Alcoholic liver disease management & $\begin{array}{l}\text { https: } / / \text { terms.naver.com } / \text { entry.nhn? } \mathrm{docId}=2704307 \& \mathrm{cid}=55588 \& \\
\text { categoryId }=55588 \& \text { expCategoryId }=55588 \\
\text { (accessed on } 28 \text { August 2019) }\end{array}$ \\
\hline & 6. Standard of proper drinking amount & $\begin{array}{l}\text { https: } / \text { / terms.naver.com } / \text { entry.nhn?docId }=2704308 \& \text { cid }=55588 \& \\
\text { categoryId }=55588 \& \text { expCategoryId }=55588 \\
\text { (accessed on } 28 \text { August 2019) }\end{array}$ \\
\hline & 7. Liver health, exercise and weight control & $\begin{array}{l}\text { https: } / \text { / terms.naver.com / entry.nhn?docId=2704346\&cid }=55588 \& \\
\text { categoryId }=55588 \\
\text { (accessed on } 29 \text { August 2019) }\end{array}$ \\
\hline & 8. Diet management of liver disease & $\begin{array}{l}\text { https:// www.dietitian.or.kr/work/business/kb_c_liver.do } \\
\text { (accessed on } 29 \text { August 2019) }\end{array}$ \\
\hline
\end{tabular}

\subsection{Effectiveness Survey}

Of the 30 medical personnel who agreed to use the chatbot program for followup management, 23 were selected as participants. Four who reported normal results (A) on all examinations (and thus did not require follow-up) and three who did not complete the survey were excluded. There were 14 males and nine females; the largest proportion $(39.12 \%)$ were in their 30s. In terms of content comprehension and content specificity, $17(73.91 \%)$ and $18(78.26 \%)$ participants were satisfied (very satisfied, slightly satisfied), respectively. However, in terms of ease of use and ease of completion, 11 $(47.83 \%)$ and $13(56.52 \%)$ respondents, respectively, were satisfied (very satisfied, slightly satisfied), respectively, reflecting less satisfaction with the program's ease than with content comprehension and specificity. In terms of the need for follow-up management chatbots, 21 $(91.30 \%)$ respondents indicated that chatbots are needed (very necessary, slightly needed); fewer respondents $(16 ; 69.56 \%)$ said that such chatbots could contribute to healthcare (very, very slightly). Finally, 14 respondents $(60.87 \%)$ reported overall satisfaction (very satisfied, slightly satisfied) (Table 2). 
Table 2. Characteristics of participants and the effectiveness of the chatbot program for follow-up management.

\begin{tabular}{|c|c|c|c|}
\hline Characteristics & & Participant (n) & Participant (\%) \\
\hline \multirow{2}{*}{ Gender } & male & 14 & 60.88 \\
\hline & female & 9 & 39.12 \\
\hline \multirow{4}{*}{ Age } & $20-29$ & 6 & 26.09 \\
\hline & $3-39$ & 9 & 39.12 \\
\hline & $4-49$ & 6 & 26.09 \\
\hline & $5-59$ & 2 & 8.70 \\
\hline \multirow{3}{*}{$\begin{array}{c}\text { Content } \\
\text { understanding }\end{array}$} & High & 17 & 73.91 \\
\hline & Moderate & 4 & 17.39 \\
\hline & Low & 2 & 8.70 \\
\hline \multirow{3}{*}{ Content specificity } & High & 18 & 78.26 \\
\hline & Moderate & 3 & 13.04 \\
\hline & Low & 2 & 8.70 \\
\hline \multirow{3}{*}{ Convenience of use } & High & 11 & 47.83 \\
\hline & Moderate & 7 & 30.43 \\
\hline & Low & 5 & 21.74 \\
\hline \multirow{3}{*}{$\begin{array}{l}\text { Configuration } \\
\text { convenience }\end{array}$} & High & 13 & 56.52 \\
\hline & Moderate & 4 & 17.39 \\
\hline & Low & 6 & 26.09 \\
\hline \multirow{3}{*}{ Needs of Program } & High & 21 & 91.30 \\
\hline & Moderate & 0 & 0.00 \\
\hline & Low & 2 & 8.70 \\
\hline \multirow{3}{*}{$\begin{array}{c}\text { Contribution to } \\
\text { health }\end{array}$} & High & 16 & 69.56 \\
\hline & Moderate & 5 & 21.74 \\
\hline & Low & 2 & 8.70 \\
\hline \multirow{3}{*}{ Overall satisfaction } & High & 14 & 60.87 \\
\hline & Moderate & 6 & 26.09 \\
\hline & Low & 3 & 13.04 \\
\hline
\end{tabular}

\subsection{Applicability to the Occupational Health Service}

Nurses working at the agency of occupational health management highly appreciated the chatbot program, as it was especially useful as a tool for solving accessibility among the difficulties in follow-up management and as an aid for explaining examination results and recommended actions. Furthermore, they suggested that accessibility and applicability would improve if question-and-answer functions were added. However, they expressed concern about the chatbot's inconvenience for use and accessibility for elderly workers. A summary of the interview results is shown in Table 3.

Table 3. Summary of interviews on the applicability of the chatbot program to the occupational health service.

\begin{tabular}{ll}
\hline \multicolumn{1}{c}{ Question } & \multicolumn{1}{c}{ Answer } \\
\hline & (1) In many cases, compliance with the follow-up management is poor for personal or business reasons. \\
$\begin{array}{l}\text { Difficulties of follow-up } \\
\text { management in occupational }\end{array}$ & $\begin{array}{l}\text { again. } \\
\text { (2) Thecause the visit cycle is long, if you do not meet once, it will take a lot of time until the opportunity comes } \\
\text { (4) It is not possible to confirm whether the workers perform the necessary follow-up management. }\end{array}$ \\
\hline $\begin{array}{l}\text { Evaluation of the chatbot program } \\
\text { for follow-up ma nagement }\end{array}$ & $\begin{array}{l}\text { (1) Methods of follow-up management are specific and there are a lot of videos such as YouTube, so it seems } \\
\text { to help to understand the contents. } \\
\text { (2) There are many visual tools such as graphs, so it is good to see results. } \\
\text { (3) Because it is complicated to use, it seems that elderly workers will have difficulty using it. } \\
\text { (4) Accessibility will be higher if questions and answers for interests are added. }\end{array}$
\end{tabular}


Table 3. Cont.

\begin{tabular}{ll}
\hline \multicolumn{1}{c}{ Question } & \multicolumn{1}{c}{ Answer } \\
\hline $\begin{array}{l}\text { Possibility of chatbot program for } \\
\text { follow-up management in the }\end{array}$ & $\begin{array}{l}\text { (1) It is possible that the follow-up management information can be viewed on your smartphone at any time, } \\
\text { occupational health service }\end{array}$ \\
$\begin{array}{l}\text { (2) It can be used as a material to explain the follow-up management contents to the target workers. } \\
\text { (3) It can shorten the management time of workers in follow-up management. }\end{array}$ \\
\hline
\end{tabular}

\section{Discussion}

This pilot study aimed to develop an early version of a chatbot program for follow-up management after WGHE. Another purpose was to investigate the effectiveness of use among healthcare providers and to check applicability in occupational health services among nurses in the agency of occupational health management.

The developed chatbot program is a system that generates information of followup management appropriate to the participants' condition by matching the participants' collected information (history, weight, lifestyle) with the results of the health examination. It then checks the contents of the participants' interest from the generated information. Such a system has the advantage of first showing the overall information of follow-up management necessary for the individual's situation. Then, from among the data provided, the participant can search more intensively for additional information of interest. Followup management in a health examination is not just about the individual's interests; rather, it is an additional intervention that includes steps such as diagnosis confirmation, education, and counselling for those who need further action as a result of screening. Thus, the first step of health examination should be to provide all of the follow-up management information required by the individual.

The results of our user survey regarding the chatbot program for follow-up management showed that medical practitioners were generally satisfied in terms of content comprehension $(17 ; 73.91 \%)$ and content specificity $(18 ; 78.26 \%)$. About $50 \%$ of the information comprised videos or animations less than 4 minutes in length that have been provided to the general public by professional societies affiliated with the Korean Academy of Medical Science; thus, their source may be one reason for the high level of satisfaction with content and specificity due to their evidence based evidence level. Infographics, which combine information and graphics, have attracted attention as a method for effectively delivering large amounts of data and complex information [21]. Infographics help to clarify information and data or to quickly integrate difficult information by rendering it visible. The value of infographics has been demonstrated previously. One study found that healthcare professionals already use infographics to communicate medical information to their patients and public health messages to the general public [22]. Another study found that infographics proved effective when providing information to subjects who could not access, understand, and reflect on their health-management behaviour [23].

In terms of ease of use and ease of construction, 11 (47.83\%) and 13 (56.52\%) participants, respectively, were generally satisfied, reflecting less satisfaction than with content comprehension and specificity. Previous studies mentioned that ease of use positively affects the intention to use smartphone healthcare applications [24], and the higher the ease of use, the higher the intention to continue to use it [25]. Given these results, it is necessary to intensively study how to increase usability in the future.

Regarding the need for follow-up management using chatbot programs, $21(91.30 \%)$ participants said that such chatbots were generally needed, whereas a lower proportion (16; $69.56 \%$ ) believed that they could contribute to healthcare (very, very slightly). This result is similar to previous research findings showing that, although respondents were interested in healthcare applications, they did not expect them to have any effect [26]. However, the level of satisfaction in the present study was much higher than that $(33.1 \%)$ for smartphone healthcare applications in a previous study [22]. This discrepancy may reflect greater satisfaction with a program that provides personalised medical information about one's health status than with one that provides general healthcare information. Furthermore, the 
proportion of subjects in their 20s and 30s was high $(15 ; 65.21 \%)$ in the present study, similar to a previous study that showed high acceptance of smartphone healthcare applications at younger ages [27].

Interviews with nurses working in the agency of occupational health management suggested that the chatbot would improve patient access. This improvement is because information on follow-up management could be checked at any time on a smartphone. Furthermore, they highlighted the chatbot program's usefulness for explaining necessary follow-up management information and its value for reducing the time needed for followup management. Moreover, considering a previous study showing that most occupational health management agencies have difficulty developing the necessary textbooks for safety and health education in Korea [28], this chatbot program will likely be a useful tool in safety and health education for individuals and groups. The Workers Health Center, which provides follow-up management for WGHE for small-sized enterprises formed by government, previously tried to solve the accessibility; for workers to visit the Workers Health Center and for healthcare providers to visit workplaces. The chatbot program for follow-up management presented here would provide a new and simpler way to solve the problem of accessibility, which is important in the occupational health service.

This study has some limitations. First, it was a pilot study using a preliminary version of the chatbot program. The initial version of the chatbot program developed in this study provided appropriate information when a participant pressed a button. However, recent years have seen attempts to replace text input with speech recognition technology, even aiming to grasp the intention of a question using natural language processing techniques. In the next step, technologies that can facilitate a question-and-answer process will be applied. Second, a satisfaction assessment for the general public was not performed, although there are clear differences between medical providers and members of the general public from the point of view that you are already familiar with the terms of WGHE and the content that the chatbot will provide in response. However, it was necessary to test the program after creating the initial version of the chatbot program. Because it is a follow-up management program based on one's results of a health examination, medical providers would be little significant difference to the general public at the point. In the next step, it should be planned to increase the completeness of the chatbot program and conduct satisfaction assessments among the general public. Third, the sample size is too small while proceeding with the pilot study. Likewise, no statistical analysis was performed. So, we cannot confirm statistically meaningful results. We plan to conduct large-scale research in the future to confirm statistical significance. Fourth, the chatbot program developed here focuses on comprehensive and detailed explanations of the information necessary for follow-up management. Follow-up management takes effect only when there is a change in behaviour, such as measuring blood pressure periodically or continuously exercising. However, this chatbot program cannot directly manage or support lifestyle improvement efforts. Recently, an app that helps manage smoking [19] or obesity [29] has been developed and tested. To integrate this function would be helpful for workers to change their health-related behaviour in relation to the follow-up management program.

\section{Conclusions}

In summary, a follow-up management program using chatbots in WGHE was developed for the first time in Korea. Chatbot users were generally satisfied, and it was confirmed that there are positive aspects in applying chatbot programs to occupational health services. For more practical follow-up management, in the future, it is necessary to develop an upgraded version of the chatbot program that includes a personalized question-and-answer process that supports behaviour changes with a large number of the general public. 
Author Contributions: Conceptualization, B.J.Y. and B.C.S.; methodology and software, B.J.Y. and J.Y.K.; writing—original draft preparation, B.J.Y.; writing—review and editing, B.C.S. and C.S.; data collection: S.P.C., M.C. and D.H.K.; data analysis: C.S. All authors have read and agreed to the published version of the manuscript.

Funding: This work was supported by a grant from Research year of Inje University in 0001200812100.

Institutional Review Board Statement: The study was approved by the Institutional Review Board of Busan Paik Hospital, Inje University (No. 19-0189 and 21 October 2019).

Informed Consent Statement: Informed consent was obtained from all subjects involved in the study.

Data Availability Statement: Data sharing is not applicable.

Conflicts of Interest: The authors declare no conflict of interest.

\section{Appendix A}

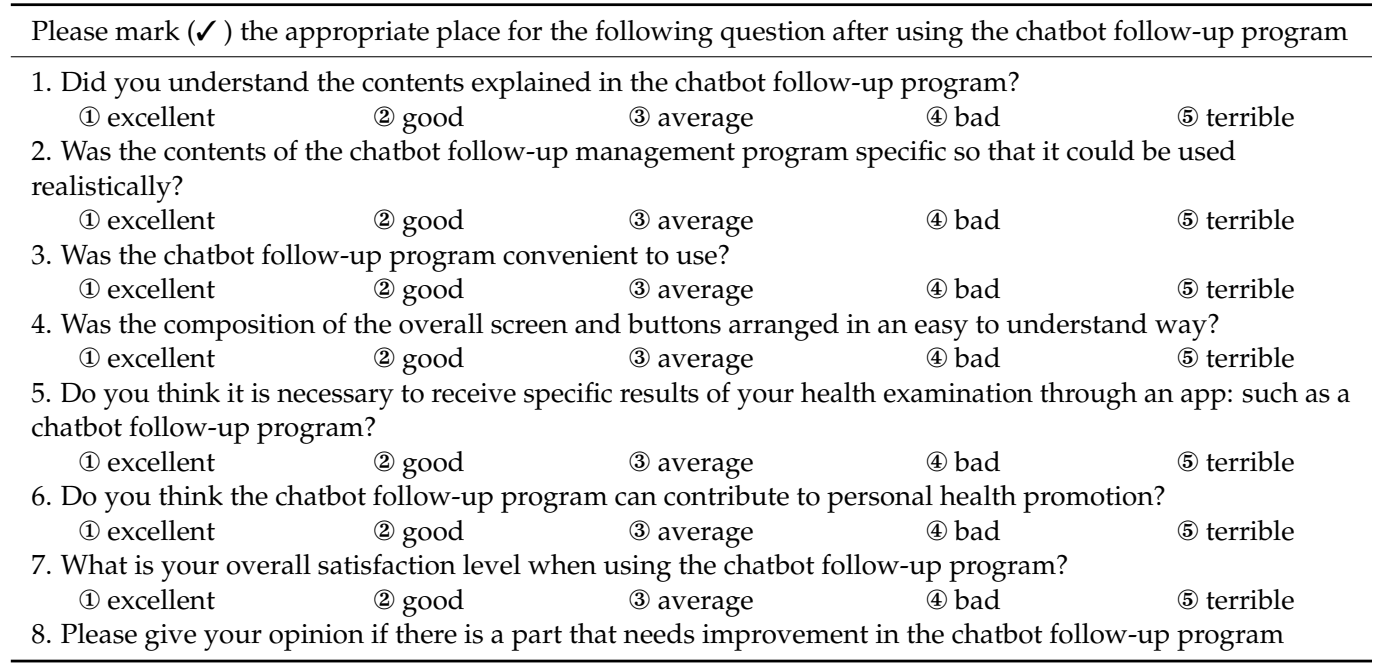

\section{References}

1. Feightner, J.W.; Battista, R.N.; Dingle, J.L. Periodic health examination. In Textbook of Family Medicine, 6th ed.; Rakel, R.E., Ed.; Saunders: Philadelphia, PA, USA, 2002; pp. 159-209.

2. Kang, Y.J.; Myong, J.P.; Eom, H.S.; Choi, B.W.; Park, J.H.; Kim, E.A. The current condition of the workers'general health examination in South Korea: A retrospective study. Ann. Occup. Environ. Med. 2017, 29. [CrossRef]

3. Lee, W.C.; Lee, S.Y. National health screening program of Korea. J. Korean Med. Assoc. 2010, 53, 363-370. [CrossRef]

4. Lee, W.C.; Lee, S.Y.; Lee, K.J.; Lee, J.H.; Lee, H.J. The Strategy to Set up the Follow-up System for the Positives and the High Risk Group Detected by National Screening Program; Report No.: Strategy 07-39; Ministry of Health and Welfare: Sejong-si, Korea, 2007; pp. 12-14. Available online: https:/ / scienceon.kisti.re.kr/srch/selectPORSrchReport.do?cn=TRKO201500007331 (accessed on 27 July 2020).

5. $\quad$ Goetzel, R.Z.; Ozminkowski, R.J.; Bruno, J.A.; Rutter, K.R.; Isaac, F.; Wang, S. The long-term impact of Johnson \& Johnson' Health \& Wellness Program on employee health risks. J. Occup. Environ. Med. 2002, 44, 417-424.

6. Low, V.; Gebhart, B.; Reich, C. Effects of a worksite program to improve the cardiovascular health of female health care workers. J. Cardiopulm. Rehabil. Prev. 2015, 35, 342-347. [CrossRef]

7. Merrill, R.M.; Sloan, A. Effectiveness of a health promotion program among employees in a western United States school district. J. Occup. Environ. Med. 2014, 56, 639-644. [CrossRef]

8. Cho, B.; Ahn, E.M. Present Status and Problems of Health Screening Program in Korea. Health Welfare Policy Forum 2013, 198, 48-54.

9. Schachner, T.; Keller, R.; Wangenheim, F. Artificial Intelligence-Based Conversational Agents for Chronic Conditions: Systematic Literature Review. J. Med. Internet Res. 2020, 22, e20701. [CrossRef]

10. Tsai, C.; Wu, J. Using neural network ensembles for bankruptcy prediction and credit scoring. Expert Syst. Appl. Pergamon 2008, 4, 2639-2649. [CrossRef]

11. Davenport, T.; Guha, A.; Grewal, D.; Bressgott, T. How artificial intelligence will change the future of marketing. J. Acad. Mark. Sci. 2019, 48, 24-42. [CrossRef]

12. Medical News. Available online: http:/ / www.mdon.co.kr/news/article.html?no=22077 (accessed on 13 June 2020 ).

13. ChatBottle. Available online: https:// chatbottle.co/bots/health-tap (accessed on 8 July 2020). 
14. Babylon. Available online: https://www.babylonhealth.com (accessed on 21 July 2020).

15. Bibault, J.E.; Chaix, B.; Guillemassé, A.; Cousin, S.; Escande, A.; Perrin, M.; Pienkowski, A.; Delamon, G.; Nectoux, P.; Brouard, B. A Chatbot Versus Physicians to Provide Information for Patients With Breast Cancer: Blind, Randomized Controlled Noninferiority Trial. J. Med. Internet Res. 2019, 21, e15787. [CrossRef] [PubMed]

16. Greer, S.; Ramo, D.; Chang, Y.J.; Fu, M.; Moskowitz, J.; Haritatos, J. Use of the Chatbot "Vivibot" to Deliver Positive Psychology Skills and Promote Well-Being AmongYoung People After Cancer Treatment: Randomized Controlled Feasibility Trial. JMIR Mhealth Uhealth 2019, 7, e15018. [CrossRef] [PubMed]

17. Park, S.; Choi, J.; Lee, S.; Oh, C.; Kim, C.; La, S.; Lee, J.; Suh, B. Designing a Chatbot for a Brief Motivational Interview on Stress Management: Qualitative Case Study. J. Med. Internet Res. 2019, 21, e12231. [CrossRef]

18. Hoermann, S.; McCabe, K.L.; Milne, D.N.; Calvo, R.A. Application of Synchronous Text-Based Dialogue Systems in Mental Health Interventions: Systematic Review. J. Med. Internet Res. 2017, 19, e267. [CrossRef] [PubMed]

19. Perski, O.; Crane, D.; Beard, E.; Brown, J. Does the addition of a supportive chatbot promote user engagement with a smoking cessation app? An experimental study. Digit. Health 2019, 9, 1-13. [CrossRef]

20. Avila-Tomas, J.F.; Olano-Espinosa, E.; Minué-Lorenzo, C.; Martinez-Suberbiola, F.J.; Matilla-Pardo, B.; Serrano-Serrano, M.E.; Escortell-Mayor, E.; the Group Dej@lo. Effectiveness of a chat-bot for the adult population to quit smoking: Protocol of a pragmatic clinical trial in primary care (Dejal@). BMC Med. Inform. Decis. Mak. 2019, 19, 249. [CrossRef] [PubMed]

21. Smiciklas, M. The Power of Infographics: Using Pictures to Communicate and Connect with Your Audiences.; Que Pub: Indianapolis, IN, USA, 2012; p. 199.

22. McCrorie, A.D.; Donnelly, C.; McGlade, K.J. Infographics: Healthcare Communication for the Digital Age. Ulst. Med. J. 2016, 85, 71-75.

23. Houts, P.S.; Doak, C.C.; Doak, L.G.; Loscalzo, M.J. The role of pictures in improving health communication: A review of research on attention, comprehension, recall, and adherence. Patient Educ. Couns. 2006, 61, 173-190. [CrossRef]

24. Beldad, A.D.; Hegner, S.M. Expanding the Technology Acceptance Model with the Inclusion of Trust, Social Influence, and Health Valuation to Determine the Predictors of German Users' Willingness to Continue Using a Fitness App: A Structural Equation Modeling Approach. Int. J. Hum. Comput. Interact. 2018, 34, 882-893. [CrossRef]

25. Cho, J.; Lee, H.E.; Quinlan, M. Complementary relationships between traditional media and health apps among american college students. J. Am. Coll. Health 2015, 63, 248-257. [CrossRef] [PubMed]

26. Dennison, L.; Morrison, L.; Conway, G.; Yardley, L. Opportunities and challenges for smartphone applications in supporting health behavior change: Qualitative study. J. Med. Internet Res. 2013, 15, e86. [CrossRef]

27. Park, M.J. Factors Affecting Intention to Use Smartphone Healthcare Applications. JKAIS 2017, 18, 143-153.

28. Kim, Y.S. A Study on Activation of Occupational Safety and Health Agency for Reducing Industrial Accidents. J. Korean Soc. Hazard Mitig. 2009, 9, 67-70.

29. Kowatsch, T.; Nißen, M.K.; Shih, I.; Rüegger, D.; Volland, D.; Filler, A.; Künzler, F.; Barata, F.; Haug, S.; Büchter, D.; et al. Text-based healthcare chatbots supporting patient and health professional teams: Preliminary results of a randomized controlled trial on childhood obesity. In Proceedings of the Persuasive Embodied Agents for Behavior Change (PEACH2017) Workshop, Co-Located with the 17th International Conference on Intelligent Virtual Agents (IVA 2017), Stockholm, Sweden, 27-30 August 2017. [CrossRef] 